\title{
Chemical mediation of bacterial surface colonisation by secondary metabolites from the red alga Delisea pulchra
}

\author{
Ria Maximilien ${ }^{1}$, Rocky de Nys ${ }^{1,3}$, Carola Holmström ${ }^{2,3}$, Lone Gram ${ }^{4}$, \\ Michael Givskov ${ }^{5}$, Katherine Crass ${ }^{1,3}$, Staffan Kjelleberg ${ }^{2,3}$, Peter D. Steinberg ${ }^{1,3, *}$ \\ ${ }^{1}$ School of Biological Science, ${ }^{2}$ School of Microbiology and Immunology, and ${ }^{3}$ Centre for Marine Biofouling and Bio-Innovation, \\ University of New South Wales, Sydney 2052, Australia \\ ${ }^{4}$ Danish Fisheries Research Institute, Department of Seafood Research, and ${ }^{5}$ Department of Microbiology, \\ The Danish Technical University, DK-2800 Lyngby, Denmark
}

\begin{abstract}
We investigated the effects of halogenated furanones from the red alga Delisea pulchra on colonisation of surfaces by marine bacteria. Bacterial abundance on the surface of $D$. pulchra, assessed using scanning electron microscopy (SEM), was significantly lower than on the surfaces of 3 co-occurring algal species, all of which lack furanones. There was also a strong inverse correlation between bacterial abundance and furanone content (previously determined) for different sections of the thallus of $D$. pulchra, consistent with inhibition of bacteria by furanones. Based on these observations we experimentally investigated inhibition of marine bacteria by furanones, initially testing the effects of crude extract of $D$. pulchra (about $50 \%$ of which is furanones) on the growth of 144 strains of bacteria isolated from the surfaces of $D$. pulchra, nearby rocks, or a co-occurring alga (Sargassum vestitum). This crude extract did not strongly inhibit growth of these bacteria; $79 \%$ of the strains grew at $50 \mu \mathrm{g} \mathrm{ml}^{-1}$ of crude extract, and $63 \%$ grew at $500 \mathrm{Hg} \mathrm{ml}^{-1}$. Inhibition of growth that did occur was strongly source dependent, with bacteria isolated from rocks the least affected, and strains from $D$. pulchra the most. As inhibition of growth did not provide an adequate explanation for the inverse relationship between levels of furanones and bacteria abundance on $D$. pulchra, we proceeded to investigate the effects of these metabolites on other bacterial characteristics relevant to colonisation-attachment, swarming, and swimming. lndividual furanones or crude extract at natural concentrations strongly inhibited bacterial attachment in the laboratory and in the field. In laboratory assays, attachment of 3 strains isolated from rocks was much more strongly affected than that of 3 isolates from $D$. pulchra, in contrast to the pattern for growth inhibition. We also tested individual furanones against swimming and swarming of the same 6 bacterial isolates ( 3 from rocks, 3 from $D$. pulchra) used in the attachment assays. At least some furanones inhibited swarming or swimming at non-growth-inhibitory concentrations for all isolates, again indicating specific effects against bacterial characteristics. As for attachment, there were significant differences in the responses of different isolates to furanones. We also found that the ability to swarm was widespread among these surface associated marine bacteria, suggesting that swarming may be ecologically important in these systems. Overall, we found that the effects of furanones on bacteria varied among (1) furanones, (2) bacterial phenotypes, (3) different isolates and (4) different sources of isolation (e.g. rocks or algae). This differential inhibition of different bacterial isolates or phenotypes by furanones, as well as affecting overall bacterial abundance on the alga, should have strong effects on the species composition of the bacterial community on the alga's surface. The effects of furanones on specific bacterial colonisation traits are discussed in the light of recent evidence demonstrating that furanones interfere with bacterial acylated homoserine lactone regulatory systems.
\end{abstract}

KEY WORDS: Marine bacteria - Delisea pulchra $\cdot$ Biofouling $\cdot$ Secondary metabolites · Attachment Swarming $\cdot$ Furanones

\section{INTRODUCTION}

Research in marine chemical ecology has to date focussed almost entirely on chemical mediation of inter- actions between eukaryotes. Consequently, as Hay (1996) has pointed out, 'The chemical ecology of marine microbes is vastly underappreciated...'. Although bacteria are ubiquitous in marine systems, in- 
cluding on or in other organisms (Sieburth 1979, Unson et al. 1994, Wahl 1996), produce unusual and biologically active secondary metabolites (Fenical 1993, Jenson \& Fenical 1994), and can have devastating effects on other marine organisms (Littler \& Littler 1995, Kushmaro et al. 1996), we know little about the role of secondary metabolites in mediating ecological interactions involving marine bacteria. This is true both for interactions between microorganisms (see Gil-Turnes et al. 1989 for a rare exception), and those between bacteria and higher organisms. There is extensive evidence that metabolites from marine eukaryotes have strong inhibitory effects against laboratory bacteria with biomedical relevance (see Hornsey \& Hilde 1974 , Reichelt \& Borowitzka 1984 for 2 of many examples), but there are remarkably few studies on the effects of characterised secondary metabolites from marine eukaryotes on marine bacteria (rare examples include Todd et al. 1993, de Nys et al. 1995).

There are even fewer studies of the effects of eukaryote secondary metabolites on marine bacteria that have a demonstrated association with the relevant eukaryotic host. A few recent studies, however, have shown that not only do metabolites from eukaryotic hosts inhibit ecologically relevant bacteria but in some instances the effects are quite specific. For example, Wahl et al. (1994) and Slattery et al. (1995) found that extracts from ascidians and soft corals (respectively) inhibited bacterial colonisation of artificial surfaces without necessarily affecting the growth of the bacteria. These effects correlated with variation in microbial fouling in the field. These studies (Wahl et al. 1994, Slattery et al. 1995) suggest that not only can secondary chemicals have important effects on microbial fouling of living marine surfaces, but such effects may be complex and subtle. In particular, compounds may interfere with different stages of the colonisation process, rather than simply being growth inhibitory or toxic. Such a defensive 'strategy' for a host organism may have several advantages over the production of toxins or antibiotics, including providing greater flexibility for inhibiting some bacteria but not others, and minimising the risk of autotoxicity due to the production of toxic metabolites at or near an organism's surface

We investigated chemical mediation of microbial fouling of the red alga Delisea pulchra (Greville) Montagne (Bonnemaisonales, Rhodophyta), a common subtidal red alga found in southeastern Australia. D. pulchra was chosen as a test organism for several reasons. It is typically unfouled by macroepiphytes in the field, and produces a range of structurally similar secondary metabolites - halogenated furanones (Kazlauskas et al. 1977, de Nys et al. 1993) - that inhibit the settlement of invertebrate larvae and algal spores, and the growth of at least 1 strain of marine bacteria (de Nys et al. 1995). Furanones also specifically interfere with the bacterial genetic regulatory system known as the acylated homoserine lactone (AHL) system (Givskov et al. 1996, Kjelleberg et al. 1997), and affect specific bacterial characteristics (swarming, bioluminescence) at non-growth-inhibitory concentrations (Givskov et al. 1996, Gram et al. 1996). Thus we hypothesised that furanones would (1) inhibit colonisation of $D$. pulchra by ecologically relevant marine bacteria, and (2) act in specific ways (e.g. as opposed to being a general toxin or inhibitor of growth) against bacterial traits relevant to the colonisation of surfaces.

To test these hypotheses, we first measured bacterial distribution and abundance on Delisea pulchra and 3 co-occurring algal species, and related patterns of abundance on $D$. pulchra to previous measurements (de Nys et al. 1996b, 1998, Dworjanyn et al. in press) of furanones within or on the plant. We then experimentally investigated, in the laboratory and the field, the effects of furanones or a crude lipophilic extract from $D$. pulchra on different components of the bacterial colonisation process. These components included bacterial growth; attachment of bacteria to a surface; swimming, as a means by which bacteria can approach the surface of the alga; and swarming, in which cells exhibit coordinated multicellular motility and rapidly spread across a surface (Belas 1992, Harshey 1994). In order to investigate the possibility that bacteria from different submerged surfaces were differentially susceptible to furanones, assays were done using bacteria isolated from the surface of $D$. pulchra and from other nearby submerged surfaces.

\section{MATERIAL AND METHODS}

Bacterial distribution and abundance. The distribution and abundance of bacteria on Delisea pulchra and 3 co-occurring algal species - Laurencia rigida (Rhodomelaceae, Ceramiales), Amphiroa sp. (Corallinaceae, Cryptonemiales) and Sargassum vestitum (Fucales) - were assessed in January 1995. Five individuals of each of these species were collected at Cape Banks, at the northern headland of Botany Bay, NSW, Australia $\left(34^{\circ} 00^{\prime} \mathrm{S}, 151^{\circ} 14^{\prime} \mathrm{E}\right)$. The plants were transported directly to the laboratory in seawater and washed using a standard procedure involving $30 \mathrm{~s}$ washes of each plant in $3 \times 11$ sterile seawater to remove associated but unattached bacteria from the water and algal surface. Each plant was divided into 5 sections from holdfast to distal tip, and a small piece ( $8 \mathrm{~mm}$ diameter) was cut from each and prepared for scanning electron microscopy (SEM). Epifluorescence 
techniques were not used because background fluorescence from the algae made it too difficult to accurately count bacteria using such techniques. To prepare samples for SEM, they were fixed in $2.5 \%$ glutaraldehyde in $0.1 \mathrm{M}$ sodium cacodylate buffer made up in calcium and magnesium free artificial seawater. This was followed by alcohol/acetone dehydration, critical point drying and gold sputter coating Coated specimens were examined using a Cambridge S360 SEM operated at $5 \mathrm{kV}$. The number of bacteria per $\mathrm{cm}^{2}$ was determined for 6 random fields of view for each of the 5 sections of each alga.

Eifect of crude extract from Delisea pulchra on growth of marine isolates. The effect of the crude nonpolar extract from $D$, pulchra on growth of marine bacteria was assessed for 29 isolates from D. pulchra, 90 isolates from surfaces of submerged rocks nearby to $D$. pulchra plants, and 25 isolates from the co-occurring alga Sargassum vestitum. Five individual D. pulchra and $S$. vestitum plants were collected from Cape Banks in November 1994, washed as above and divided into 5 equal sections. Pieces $1 \mathrm{~cm}$ in diameter were cut from each section of each plant, placed in $5 \mathrm{ml}$ sterile seawater and shaken vigorously for $30 \mathrm{~min}$. A $100 \mu$ aliquot from each tube was then plated out on a VNSS agar plate (Mården et al. 1985) and incubated at room temperature for $36 \mathrm{~h}$. All colonies that visibly differed from each other in morphology and colour were isolated on agar plates. Isolates from nearby rock surfaces were obtained by swabbing, with swabs shaken in sterile seawater and bacteria plated out as above.

Crude extract of Delisea pulchra used in these growth assays was prepared by freeze drying whole thalli of $D$. pulchra, extracting in dichloromethane, and rotary evaporating to dryness. The resulting extract is approximately $50 \%$ furanones by weight, of which $90+\%$ is represented by the 4 metabolites shown in Fig. 1 (de Nys et al. 1993, de Nys et al. 1996b). To test the effects of this extract against the bacterial isolates, it was dissolved in ethyl acetate and incorporated into molten VNSS media $(1.5 \%$ Oxoid agar $)$ at $52^{\circ} \mathrm{C}$ to final concentrations of $0.5,5,50$ and $500 \mathrm{\mu g} \mathrm{m}^{-1}$ (equal volumes of solvent were added for all concentrations). Two replicate plates of each treatment, including ethyl acetate and media controls, were poured to a standard thickness prior to inoculation. Isolates from D. pulchra, Sargassum vestitum, or rocks were pre-cultured overnight at room temperature in VNSS media. $10 \mu \mathrm{l}$ of the suspension was then drop inoculated onto each plate, with results scored visually as growth (obvious colonies) or no growth after $36 \mathrm{~h}$.

Attachment. The effects of furanones or crude extract on the attachment of marine bacteria to artificial surfaces were measured in the laboratory and in the field at Cape Banks. Crude extract was prepared as described above. Individual furanones (compounds 2 and 3; Fig. 1) were isolated as described in de Nys et al. (1993) and Givskov et al. (1996). Crude extract or metabolites were dissolved in ethanol so as to give final concentrations of $0 \mathrm{ng} \mathrm{\textrm {cm } ^ { - 2 }}$ (e.g. controls), $10 \mathrm{ng}$

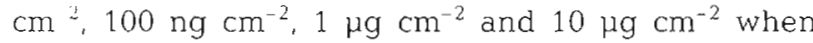
$400 \mathrm{ml}$ was applied to $11 \mathrm{~cm}^{2}$ circular perspex disks (crude extract only) or glass petri dishes. These concentrations span the range of concentrations of furanones (typically 10 to $500 \mathrm{ng} \mathrm{\textrm {cm } ^ { - 2 }}$, depending on the compound) or crude extract (100s of $\mathrm{ng}$ to $1 \mathrm{\mu g} \mathrm{cm} \mathrm{cm}^{-2}$ ) found on the surface of Delisea pulchra (de Nys et al. 1998, Dworjanyn et al. in press). The disks had a slightly raised edge which allowed complete coverage of the surface with ethanol without loss. Disks were dried for $1 \mathrm{~h}$ and then attached (randomly with regards to treatment) to a plastic grid with $5 \mathrm{~cm}$ between disks. Both glass and perspex surfaces were used in assays with crude extract in order to assess whether the effect of the extract was dependent on the surface on which it was applied. However, only glass petri dishes were used for tests of pure furanones, as we found that we could not achieve a homogeneous spread of the pure metabolites on perspex.

To measure bacterial attachment in the field, the array of coated disks was suspended vertically $50 \mathrm{~cm}$ above a bed of Delisea pulchra at Cape Banks at a depth of $2 \mathrm{~m}$ using 1 weight below and 4 floats at each corner of the grid deployed vertically. Three disks per concentration of furanones or crude extract (including ethanol and uncoated controls) were used. Because of limitations on the number of disks which could be deployed and then counted at one time, crude extract and each furanone were tested in separate experiments. After $2 \mathrm{~h}$, the array was returned directly to the laboratory in seawater for washing, staining and counting. Disks were washed to remove unattached cells by immersing the array in $3 \times 1 \mathrm{l}$ sterile seawater for $10 \mathrm{~s}$ with shaking, and stained with $10 \mu \mathrm{g} \mathrm{ml}^{-1} 4,6$ diamidino-2-phenylindole (DAPI) in artificial seawater. Cells were visualised at $\times 1000$ magnification using an Olympus BH2 epifluorescence microscope (excitation $\lambda=350 \mathrm{~nm}$; emission $\lambda=450 \mathrm{~nm}$ ). The number of cells per field was counted for 12 fields in the central portion of each plate.

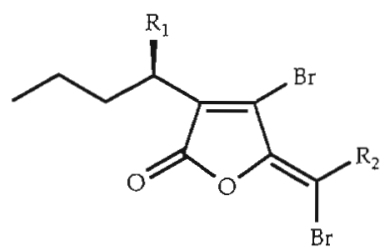

R1 R2

(1) $\mathrm{H} \quad \mathrm{Br}$

(2) $\mathrm{H} \mathrm{H}$

(3) OAC $\mathrm{H}$

(4) $\mathrm{OH} \quad \mathrm{H}$

Fig. 1. Structure of furanones 1 to 4 from Delisea pulchra 
These field assays measured the effects of metabolites on attachment of the mixed assemblage of bacteria present in the field. In order to determine whether host versus non-host strains of bacteria differed in their ability to attach to surfaces in the presence of furanones, the attachment to surfaces coated with crude extract of 3 bacterial strains isolated from Delisea pulchra, and 3 isolated from nearby submerged rocks, was assessed in the laboratory (see below for details of isolation procedure and strain selection). Each strain was cultured at room temperature in $250 \mathrm{ml}$ VNSS medium until reaching $\mathrm{OD}_{595}=0.7$. Cells were removed by centrifugation at $15000 \times g$ for $10 \mathrm{~min}$ and resuspended in 11 sterile seawater in a large glass container. The array of disks coated with crude extract was immersed in the bacterial suspension for $2 \mathrm{~h}$ at room temperature with shaking. Concentrations of crude extract tested were the same as for the field experiment, and there were again 3 disks per treatment. After $2 \mathrm{~h}$, the disk arrays were removed from the containers, washed, and the bacteria stained and counted (in 12 fields of view per disk) as described above.

Isolation, selection, and assays of suriace-associated bacterial isolates. In order to look in greater detail at the phenotypic response of individual bacterial strains to individual furanones, 3 strains of bacteria were selected from those isolated from Delisea pulchra, and 3 from those isolated from nearby rocks, and the effects of furanones 1 to 4 on swimming, swarming, and growth investigated (these strains were also tested against crude extract in the laboratory attachment assay described above). The selection of these 6 isolates was based on (1) their distinctly differing morphologies, minimising the chance that 2 or more isolates were in fact the same bacterial strain, and (2) the ability of the isolates to swarm, swim, attach (above) and grow under our laboratory culture conditions. We found that of all these assays, swarming was the least predictable and most sensitive to environmental conditions, and selection of the 6 strains was thus ultimately determined by our ability to establish a consistent swarming assay with each strain.

Swarming. Bacterial swarming occurs when cells in a colony elongate, hyperflagellate, and then rapidly spread across a surface in a coordinated fashion (Belas 1992, Harshey 1994). On agar plates, swarming is evident (macroscopically) as a series of concentric rings of swarmer cells on the surface of the agar. Using these criteria, 180 bacterial isolates from the surfaces of Delisea pulchra and rocks were screened for swarming motility on agar plates. Since swarming is affected by the composition and viscosity of the media, 2 media [VNSS and LB20 $(5.0 \mathrm{~g}$ yeast extract, $10.0 \mathrm{~g}$ tryptone, $20.0 \mathrm{~g} \mathrm{NaCl}$ made up to $1 \mathrm{l})$ ] and 4 agar concentrations (0.4 to $1.0 \%$ Oxoid agar) were used in the screening.
Plates, including 2 replicates of each media and agar concentration, were poured to a standard thickness and dried for $1 \mathrm{~h}$. Isolates were pre-cultured in VNSS media overnight at room temperature, stab inoculated in the centre of each plate, then incubated at room temperature $\left(22\right.$ to $\left.24^{\circ} \mathrm{C}\right)$. Plates were observed regularly over $48 \mathrm{~h}$. The colony rim of isolates exhibiting macroscopic surface colonisation was observed under light microscopy at $\times 400$ magnification to evaluate if cells were differentiated into elongated hyperflagellated cells displaying coordinated multicellular motility, as described for classic swarming motility (Belas 1992).

Approximately $25 \%$ (overall) of the isolates tested swarmed. Of these, the behaviour of 3 isolates from Delisea pulchra (designated V21, V54, V55) and 3 from rock surfaces (designated R12, R86, R130) was most consistent and these strains were chosen for subsequent testing of swarming, swimming, growth, and attachment (attachment assays described above). Rock strains swarmed best on LB20 media, while the strains from $D$. pulchra swarmed best on VNSS media. To be consistent across different assays, these media were then also used in subsequent tests of swimming and growth. Thus, unlike the analysis of the laboratory attachment assay, use of these 2 media for the 2 groups of isolates prevented a formal comparison of the effects of furanones on isolates from different sources (D. pulchra vs rocks).

Swarming in the presence of furanones 1 to 4 was assessed for the 6 bacterial isolates by first dissolving furamones in ethanol and then incorporating them into molten LB20 or VNSS semisolid media $(0.4$ to $0.6 \%$ Oxoid agar) at $52^{\circ} \mathrm{C}$ to final concentrations of 5,25 and $50 \mu \mathrm{g} \mathrm{ml}^{-1}$ (all 4 furanones are heat stable to $>100^{\circ} \mathrm{C}$. $\mathrm{R}$. de Nys unpubl.). These plates, including 3 replicates of each treatment (including media and ethanol controls), were poured immediately to a standard thickness and dried for $1 \mathrm{~h}$. Isolates were pre-cultured overnight at room temperature $\left(22\right.$ to $\left.24^{\circ} \mathrm{C}\right)$ in the appropriate media, stab inoculated in the centre of each plate, then incubated at room temperature. The radius of colony spread over $48 \mathrm{~h}$ was taken as a measure of swarming.

Swimming. In contrast to swarming, bacterial swimming occurs in an uncoordinated fashion, in which the cells swim through-water channels within the semisolid agar, forming chemotactic rings, the radius of which can be measured from the point of inoculation and used as an assay parameter (Eberl et al. 1996a). Swimming in the presence of furanones 1 to 4 was assessed for 6 bacterial isolates by dissolving furanones in ethanol and incorporating them into molten LB20 or VNSS semisolid media $(0.2 \%$ Oxoid agar) at $52^{\circ} \mathrm{C}$ to final concentrations of 5,25 and $50 \mu \mathrm{g} \mathrm{ml}-1$ Three replicate plates, poured to a standard thickness and dried for $1 \mathrm{~h}$, were used for each treatment, includ- 
ing plain media and ethanol controls. As for swarming, isolates were pre-cultured overnight at room temperature $\left(22\right.$ to $\left.24^{\circ} \mathrm{C}\right)$ in the appropriate media, stab inoculated in the centre of each plate, then incubated at room temperature. The radius of the colony measured from the point of inoculation (Eberl et al. 1996a, Givskov et al. 1996) after $48 \mathrm{~h}$ was used as our measurement of swimming velocity.

Growth. The effects of furanones 1 to 4 on growth of the 6 bacterial isolates were assessed in liquid media. Furanones were dissolved in ethanol and incorporated into either LB20 or VNSS media at 5, 25 and $50 \mu \mathrm{g} \mathrm{ml}^{-1}$. $200 \mathrm{hl}$ media was added to each well of a Nunc 96-well tissue culture plate, with 3 replicates of each treatment including ethanol and media controls. Isolates were pre-cultured in LB20 or VNSS media overnight at room temperature, diluted $1: 10$ in the appropriate media, then $20 \mu \mathrm{l}$ added to each well. Growth was measured as absorbance at $595 \mathrm{~nm}$ hourly for $24 \mathrm{~h}$ in a BioRad 3550 Microplate Reader.

Statistical analyses. Variation in the abundance of bacteria on algae, and the effects of furanones or crude extract from Delisea pulchra on swimming, attachment, growth in liquid media and swarming were analysed using Analysis of Variance (ANOVA) followed by Tukey's simultaneous multiple range test (Day \& Quinn 1989) for comparison among treatment means. Cochran's test was used to check for homogeneity of variances (Sokal \& Rohlf 1995). In most instances data were transformed by $\ln (x+1)$ to ensure normality and homoscedasticity. Analyses were done using the statistical software DataDesk and Systat for Macintosh computers. Factors in analyses of the effects of furanones or extracts typically included Concentration, Bacterial Isolate, and, where individual furanones were used (compounds 1 to 4 as per Fig. 1), Furanone (see Tables 4 to 6 ). In laboratory attachment assays, Source (whether a particular strain was obtained from rocks or algae) was included as a factor, with Isolate nested within Source. Analysis of attachment assays - in which several fields of view were counted per experimental plate or petri dish-also typically incorporated Plate or Dish as an additional nested factor. Nested factors were pooled for $p>0.3$ (Underwood 1981). 'Position' on plants (Table 1) was treated as an orthogonal factor, as we assumed that $1 \mu \mathrm{m}$ long bacteria separated by at least several centimetres on an algal thallus could be treated as independent units. Growth inhibition of isolates from different sources (D. pulchra, rocks, and Sargassum vestitum) was analysed via chi-square. Additional detail for some experiments is given in the 'Results' section.
Table 1 Analysis of variance (ANOVA) of bacterial abundance on 4 co-occurring algal species: Delisea pulchra, Sargassum vestitum, Amphiroasp. and Laurencia rigida. Analysis based on numbers of cells in $N=6$ fields of view for each of 5 positions on each of 5 plants from each species, as measured via scanning electron microscopy (SEM)

\begin{tabular}{|lrrrc|}
\hline & df & MS $\left(\times 10^{13}\right)$ & F-ratio & p-value \\
\hline Species & 3 & 700.1 & 124.2 & $<0.0001$ \\
Plant (Species) & 16 & 5.6 & 1.4 & 0.21 \\
Position & 4 & 82.9 & 14.4 & $<0.0001$ \\
Spp. $\times$ Position & 12 & 68.3 & 11.9 & $<0.0001$ \\
Plant $\times$ Position & 16 & 5.8 & 1.5 & 0.2 \\
Error & 548 & 3.9 & & \\
\hline
\end{tabular}

\section{RESULTS}

\section{Bacterial distribution and abundance}

Bacterial abundance along the thallus of Delisea pulchra varied by more than an order of magnitude, from approximately $10^{6}$ cells $\mathrm{cm}^{-2}$ at the apical tip of the plant to $>10^{7}$ cells $\mathrm{cm}^{-2}$ at the base (Fig. 2). Abundance of bacteria on the 2 basal sections of $D$. pulchra differed significantly from abundance on the 3 uppermost sections (ANOVA as per Table 1 followed by Tukey's test, $\alpha=0.05$ ). This pattern is inversely correlated with changes in furanone levels in (de Nys et al. 1996b) or on the surface of (Dworjanyn et al. in press) D. pulchra. Bacterial abundance on the co-occurring algal species Sargassum vestitum, Amphiroa sp. and Laurencia

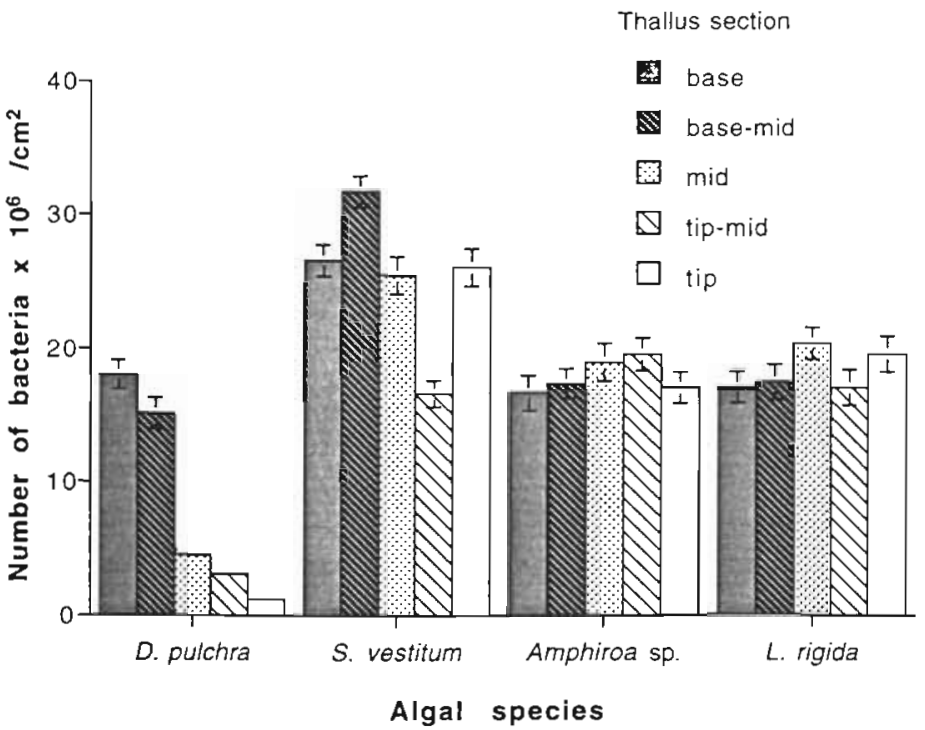

Fig. 2. Bacterial abundance on the surfaces of the seaweeds Delisea pulchra Sargassum vestitum, Amphiroa sp. and Laurencia rigida Numbers of bacteria were counted in 6 fields of view from 5 positions on the thallus for 5 individuals of each species. Data are mean $+\mathrm{SE}$ $(\mathrm{N}=30)$ for each position for each species 


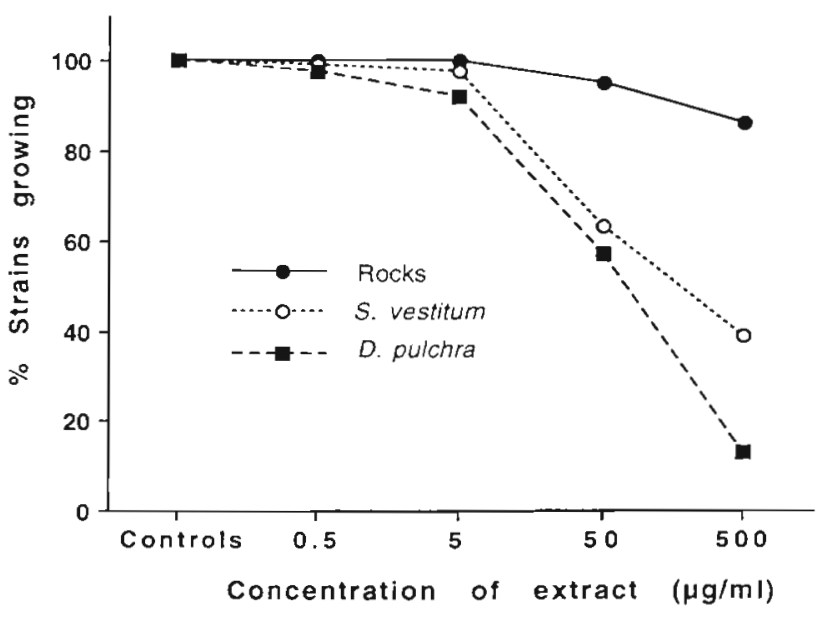

Fig. 3. Percentage of bacterial isolates from 3 marine surfaces (the algae Delisea pulchra and Sargassum vestitum, and nearby submerged rocks) growing in the presence of crude extract from $D$. pulchra when incorporated into $1.5 \%$ VNSS agar at the concentrations shown. $N$, the number of strains isolated and tested from each surface, was 29 for $D$. pulchra, 25 for $S$. vestitum, and 90 for rocks

rigida was comparable to abundance on the basal sections of $D$. pulchra, but significantly higher than that on the more distal sections (Fig. 2; Tukey's tests). In contrast to $D$. pulchra, there was relatively little variation-and no consistent pattern - in the abundance of bacteria among different parts of the thalli of Amphiroa sp., S. vestitum or L. rigida (Fig. 2). Bacteria on these other algae, and on the lower parts of the thallus of $D$. pulchra, appeared to form confluent biofilms. In contrast, bacteria on the more distal sections of $D$. pulchra were patchily distributed, often occurring as one or a few isolated cells.

\section{Effects oi crude extract on growth}

Overall, the crude extract of Delisea pulchra was not strongly growth inhibitory against 144 ecologically relevant bacterial strains isolated from $D$. pul- chra $(\mathrm{N}=29$ strains), Sargassum vestitum $(\mathrm{N}=25)$ or rocks $(\mathrm{N}=90)$. At $5 \mu \mathrm{g} \mathrm{ml}^{-1}$, only $1 \%$ of the strains failed to grow, and $63 \%$ of the strains still grew at the very high concentration of $500 \mathrm{~kg} \mathrm{ml}^{-1}$. However, the effects of the extract on growth varied strongly as a function of the surface from which strains were isolated (Fig. 3; 2-way chi-square with factors Source and Concentration, $\mathrm{df}=10, \chi^{2}=339, \mathrm{p}<0.0001$ ). Surprisingly, growth of isolates from rocks was much less sensitive to $D$. pulchra crude extract than isolates from $D$. pulchra. For example, $500 \mu \mathrm{g} \mathrm{ml}^{-1}$ of crude extract inhibited growth of $13.3 \%$ of the isolates from rocks, but $86.2 \%$ of the isolates from $D$. pulchra (Fig 3). The effect of crude extract on growth of bacteria isolated from the surface of the brown alga $S$. vestitum was intermediate between that of isolates from rocks and $D$. pulchra. These differences in inhibition of isolates from the different sources were significant at $p=0.05$ for concentrations of 50 and $500 \mu \mathrm{g} \mathrm{ml}^{-1}$ of extract. This conclusion was based on a 1-way $\chi^{2}$ for these data where classes consisted of each combination of source and concentration, followed by the pairwise comparison procedure outlined in Sokal \& Rohlf (1995, p. 723-724). At a concentration of crude extract of $50 \mu \mathrm{g} \mathrm{ml}^{-1}$, the percent of strains growing from the different sources followed the pattern, rock $=S$. vestitum $>D$. pulchra strains. At $500 \mu \mathrm{g} \mathrm{ml}^{-1}$, the pattern was rock strains $>S$. vestitum $=D$. pulchra strains. In these growth assays the results (growth or no growth) of the 2 replicates (per isolate per concentration) were identical in all cases. As suggested by the numbers of isolates tested from the different sources, isolation of bacteria from rocks typically resulted in higher numbers of distinguishable strains than isolation from $D$. pulchra or $S$. vestitum.

The ability of most strains to grow even at high concentrations of crude extract did not provide an adequate explanation for the low numbers of bacteria on Delisea pulchra relative to other co-occurring algae, nor for the inverse correlation between furanone levels and bacterial numbers along the thallus of this alga. We thus proceeded to test the effects of furanones

Table 2. Nested analyses of variance for field bacterial attachment assays (Fig. 4). (A) Analysis of the effects on bacterial attachment of crude extract of Delisea pulchra coated onto plastic surfaces. (B) Crude extract on glass. (C) Furanone 2 on glass. (D) Furanone 3 on glass. $N=6$ to 12 fields of view counted for each plate ( 2 to 3 plates per concentration). The nested factor Plate was non-sıgnificant $(p=0.42)$ in the initial analysis in $A$ and was pooled

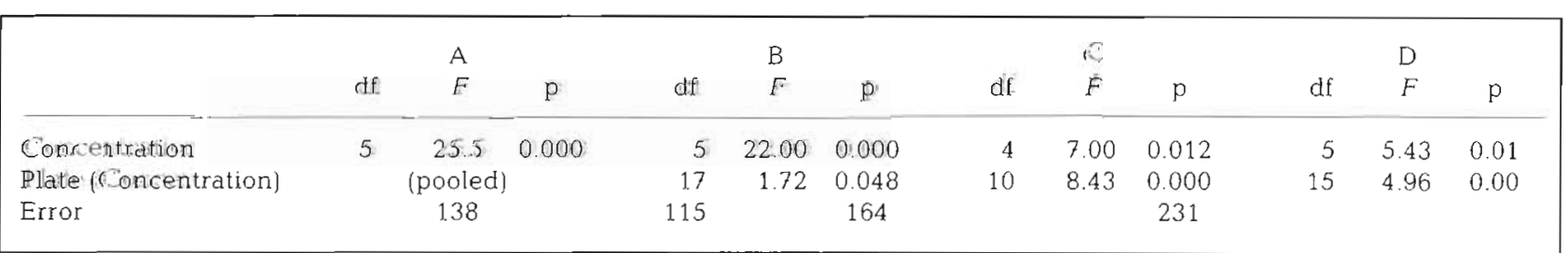




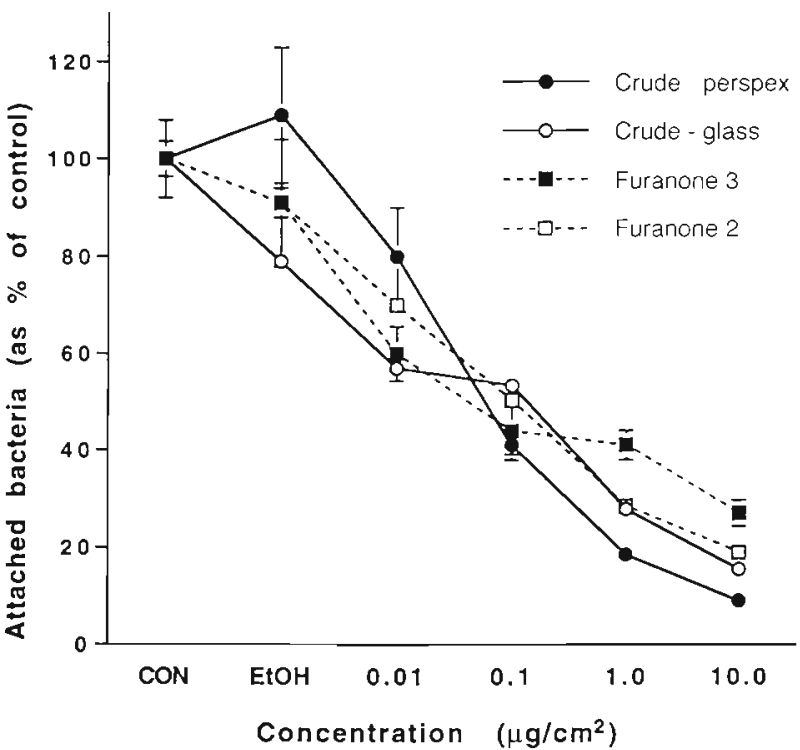

Fig. 4. Attachment of bacteria in the field to surfaces coated with crude extract from Delisea pulchra or furanones 2 or 3. Data are mean ( $\pm \mathrm{SE}$ ) numbers of attached cells expressed as percentage of cells attached to uncoated control surfaces (at higher concentrations standard errors were often smaller than the symbols used). Tests with crude extract were done on both glass and plastic; those with pure compounds on glass only (see 'Material and methods'). EtOH (ethanol) surfaces were coated with this solvent only. $\mathrm{N}=14$ to 36 ( 2 or 3 plates per concentration $\times 6$ to 12 fields of view)

against other bacterial characteristics relevant to the colonisation of surfaces.

\section{Attachment}

Crude extract, and furanones 2 and 3 (Fig. 1), strongly inhibited attachment of bacteria in the field

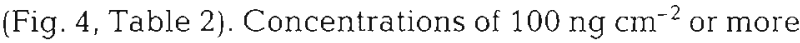
were inhibitory in all assays [Fig. 4, ANOVA (Table 2) followed by Tukey's test, $\alpha=0.05$ ], and concentrations as low as $10 \mathrm{ng} \mathrm{cm}^{-2}$ were inhibitory in some tests. A concentration of $1.0 \mu \mathrm{g} \mathrm{cm}^{-2}$ of crude extract (contain-

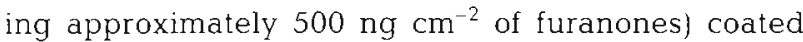
onto perspex or glass disks reduced the number of attached bacteria to less than $20 \%$ of control numbers (Fig. 4). Concentrations tested reflect the natural concentrations of crude extract or individual compounds found on the surface of D. pulchra (de Nys et al. 1998, Dworjanyn et al. in press).

The 6 bacterial strains (V21, V55, and V54 from Delisea pulchra, and R86, R12, R130 from nearby rocks) tested individually were also strongly inhibited by crude extract of $D$. pulchra in laboratory assays (Fig. 5, Table 3). As was the case for growth, the source

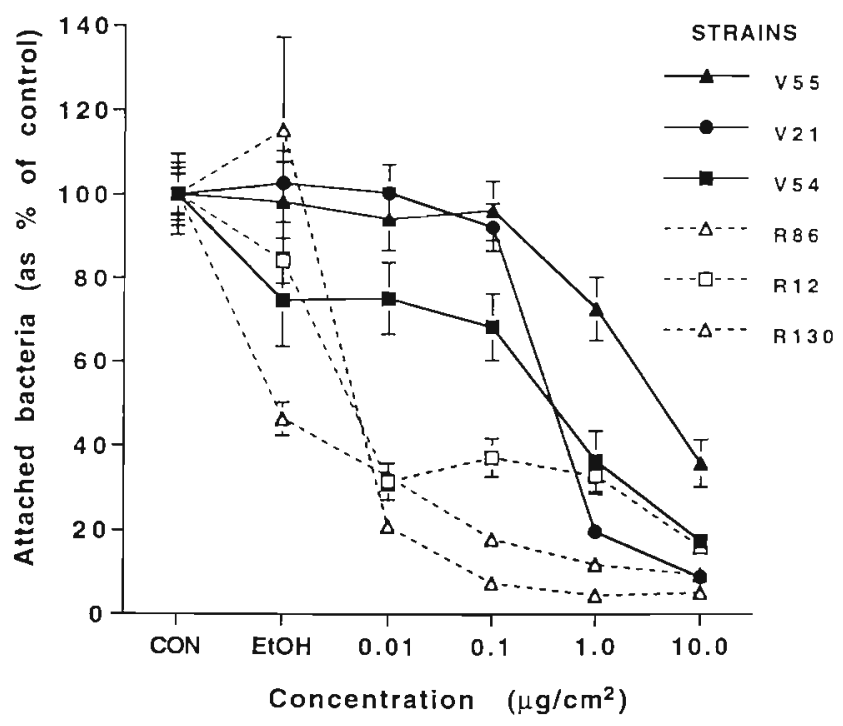

Fig. 5. Attachment of cells of 6 bacterial isolates in the laboratory to perspex coated with crude extract of Delisea pulchra at the concentrations shown, expressed as percentage of cells on uncoated control surfaces. Three strains (V55, V21, and V54) were isolated from the surface of $D$. pulchra and 3 (R86, R12, $\mathrm{R} 130$ ) from nearby submerged rocks. Data are mean ( $\pm \mathrm{SE}$ ). $N=24$ to 36 (12 fields of view counted for 2 or 3 perspex plates per strain per concentration)

of the isolates strongly affected their response in these assays. However, in contrast to the results for the growth screen, attachment of strains isolated from rocks was on average inhibited at significantly lower concentrations than that of strains isolated from $D$. pulchra (Fig. 5: Table 3, note 'Source' effect). Attachment of rock strains was highly sensitive to the presence of extract; concentrations of $10 \mathrm{ng} \mathrm{cm} \mathrm{cm}^{-2}$ significantly inhibited attachment of all 3 rock strains, relative to solvent controls (Table 3; Tukey's test, $\alpha=0.05$ ). Attachment of strains from $D$. pulchra was not significantly inhibited below concentrations of $1 \mu \mathrm{g} \mathrm{cm} \mathrm{cm}^{-2}$ (Fig. 5, Table 3 followed by Tukey's test).

Table 3. Analysis of variance of the number of bacteria [transformed by $\ln (x+1)]$ attached to plastic surfaces coated with Delisea pulchra crude extract in laboratory assays. $N=25$ to 36 fields of view counted for each combination of treatments after pooling the nested factor Plate (non-significant at $p>0.3$ in the initial analysis)

\begin{tabular}{|lrrrc|}
\hline Factor & df & MS & $F$ & $\mathrm{p}$ \\
\hline Source & 1 & 8.87 & 12.3 & 0.025 \\
Isolate (Source) & 4 & 0.72 & 17.97 & $<0.001$ \\
Concentration & 5 & 8.36 & 34.36 & $<0.001$ \\
Source $\times$ Concentration & 5 & 1.47 & 6.07 & 0.0014 \\
Isolate $\times$ Concentration & 20 & 0.24 & 6.07 & $<0.001$ \\
Error & 1188 & 0.04 & & \\
\hline
\end{tabular}




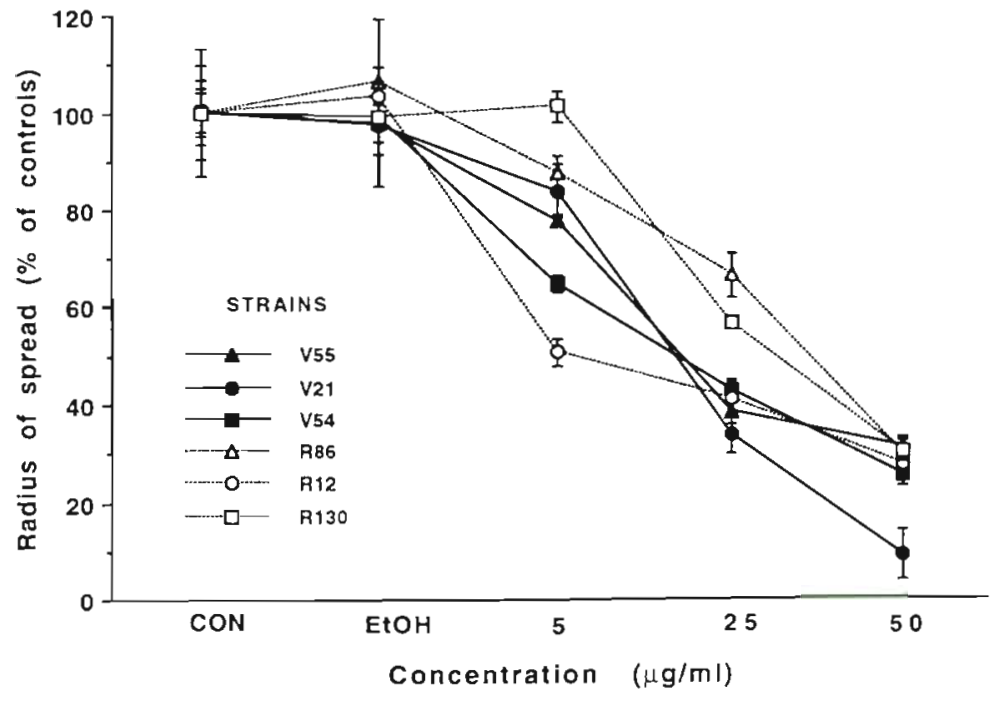

Fig. 6. Inhibition of swarming motility by furanone 2 for 3 bacterial isolates from Delisea pulchra (V55, V21, V54), and 3 from nearby submerged rocks (R86, R12, R130), tested on agar plates. Data are mean $\pm \mathrm{SE}$ for $\mathrm{N}=$ 3 plates for each strain at each concentration

\section{Tests of individual furanones against swarming, swimming, and growth for isolates from rocks and Delisea pulchra}

The minimum inhibitory concentrations (concentrations at which a statistically significant effect was observed, as based on ANOVA followed by Tukey's test at $\alpha=0.05$ ) for 4 furanones (Fig. 1) against swarming, swimming, and growth of 3 isolates from Delisea pulchra (V21, V55, and V54) and 3 isolates from nearby rock surfaces (R86, R12, R130) are summarised in Table 4. A description of specific effects follows. In order to save space, for swarming and swimming assays, only results for furanone 2 are presented graphically. For growth experiments (in which data are individual growth curves over time for each strain for each furanone at each concentration), only the relevant ANOVA (see Table 6) and the summary in Table 4 are presented.

\section{Swarming}

Of a total of 180 marine bacterial isolates screened, $11 \%$ of isolates from Delisea pulchra and $28 \%$ of isolates from rock surfaces swarmed on the test media. Swarming of all isolates was significantly inhibited by furanones (Fig. 6 for furanone 2; Tables $4 \& 5$ A), usu-

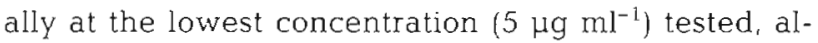
though in a few instances (furanone 3 for strains V21, V55, R130, furanone 4 for V21; see Table 4) effects on swarming could not be distinguished from effects on growth. The 4 furanones tested varied in their effects on swarming (Table 5A). Different isolates were to some extent also differentially affected by furanones (Table 5A; $\mathrm{p}=0.014$ for factor Furanones) although the overall pattern of inhibition of swarming by furanones was much more similar than for swimming (see below).

\section{Swimming}

Furanones had relatively little effect on swimming of strains isolated from rocks (Fig. 7 for furanone 2, Table 4); swimming by rock strains was often not inhibited by furanones even at the highest concentration tested (Table 4). In contrast, most furanones significantly inhibited swimming by strains from Delisea pulchra (Fig. 7. Table 4), although for some strains, such as V21, inhibition of swimming could not be distinguished from inhibition of growth (Table 4). Surprisingly, in 1 instance (furanone 3 against strain V21) swimming was unaffected at a concentration which significantly inhibited growth, perhaps suggesting a specific effect of this furanone on growth, but not swimming, of this strain.

Table 4. Minimum inhibitory concentrations of furanones from Delisea pulchra against swimming, growth and swarming of bacterial isolates from the surfaces of $D$. pulchra and nearby submerged rocks

\begin{tabular}{|c|c|c|c|c|c|}
\hline \multirow[t]{2}{*}{ Source } & \multirow[t]{2}{*}{ Isolate } & \multirow{2}{*}{ Furanone } & \multicolumn{3}{|c|}{ Inhibitory conc. $\left(\mu \mathrm{g} \mathrm{ml}^{-1}\right)$} \\
\hline & & & Swimming & Growth & Swarming \\
\hline \multirow[t]{12}{*}{ D. pulchra } & V21 & 1 & 25 & 25 & 5 \\
\hline & & 2 & 25 & 25 & 5 \\
\hline & & 3 & 25 & 5 & 5 \\
\hline & & 4 & 5 & 5 & 5 \\
\hline & V54 & 1 & 5 & $>50$ & 25 \\
\hline & & 2 & 5 & $>50$ & 5 \\
\hline & & 3 & 5 & 25 & 5 \\
\hline & & 4 & 5 & 25 & 5 \\
\hline & V55 & 1 & 5 & $>50$ & 5 \\
\hline & & 2 & 5 & $>50$ & 5 \\
\hline & & 3 & 5 & 5 & 5 \\
\hline & & 4 & 5 & 25 & 5 \\
\hline \multirow[t]{12}{*}{ Rocks } & $\mathrm{R} 12$ & 1 & $>50$ & $>50$ & 5 \\
\hline & & 2 & $>50$ & $>50$ & 5 \\
\hline & & 3 & 50 & $>50$ & 5 \\
\hline & & 4 & 25 & 25 & 5 \\
\hline & R86 & 1 & 50 & $>50$ & 25 \\
\hline & & 2 & $>50$ & $>50$ & 5 \\
\hline & & 3 & $>50$ & $>50$ & 5 \\
\hline & & 4 & 25 & 25 & 5 \\
\hline & R130 & 1. & $>50$ & $>50$ & 25 \\
\hline & & 2 & $>50$ & $>50$ & 25 \\
\hline & & 3 & $>50$ & 25 & 25 \\
\hline & & 4 & 25 & 25 & 5 \\
\hline
\end{tabular}


Table 5. Three factor analysis of variance for $\ln (x+1)$ of radius of colony spread (as proportion of control colonies) for (A) swarming and (B) swimming for 6 bacterial isolates in the presence of furanones 1 to 4 (Fig. 1), tested at a range of concentrations (see Figs. $6 \& 7$ for results for compound 2). $N=3$ plates for each combination of treatments

\begin{tabular}{|c|c|c|c|c|c|c|c|}
\hline \multirow[t]{2}{*}{ Factor } & \multirow[t]{2}{*}{$\mathrm{df}$} & \multicolumn{3}{|c|}{ (A) Swarming } & \multicolumn{3}{|c|}{ (B) Swimming } \\
\hline & & MS & F-ratio & p-value & MS & F-ratio & p-value \\
\hline Isolate & 5 & 0.077 & 2.9 & 0.014 & 1.31 & 760.4 & $<0.001$ \\
\hline Furanone & 3 & 1.029 & 38.8 & $<0.001$ & 0.71 & 409.6 & $<0.001$ \\
\hline Isolate $\times$ Furanone & 15 & 0.026 & 0.98 & 0.981 & 0.062 & 36.1 & $<0.001$ \\
\hline Concentration & 4 & 2.471 & 93.3 & $<0.001$ & 3.31 & 1922.7 & $<0.001$ \\
\hline Furanone $\times$ Concentration & 12 & 0.134 & 5.1 & $<0.001$ & 0.141 & 81.8 & $<0.001$ \\
\hline Isolate $\times$ Concentration & 20 & 0.013 & 0.49 & 0.97 & 0.26 & 151.8 & $<0.001$ \\
\hline Isolate $\times$ Concentration $\times$ Furanone & 60 & 0.10 & 0.38 & 1.00 & 0.052 & 30.1 & $<0.001$ \\
\hline Error & 240 & 0.026 & & & 0.002 & & \\
\hline
\end{tabular}

\section{Growth}

The effects of individual furanones 1 to 4 on growth over time of the 6 selected isolates in liquid media are summarised in Tables 4 \& 6 , with minimum significant inhibitory concentrations shown [ANOVA, followed by Tukey's tests (not shown), on OD measured at $595 \mathrm{~nm}$ of liquid cultures after $10 \mathrm{~h}$ ]. As indicated by the analysis (Table 6), all main variables and their interaction (with 1 exception) had significant effects on growth. The effects of different furanones on growth, and the responses of different isolates to a given furanone. varied substantially (Tables 4 \& 6), although in general furanone 4 was the most inhibitory compound, followed by furanone 3 . Isolates from $D$. pulchra appeared to be

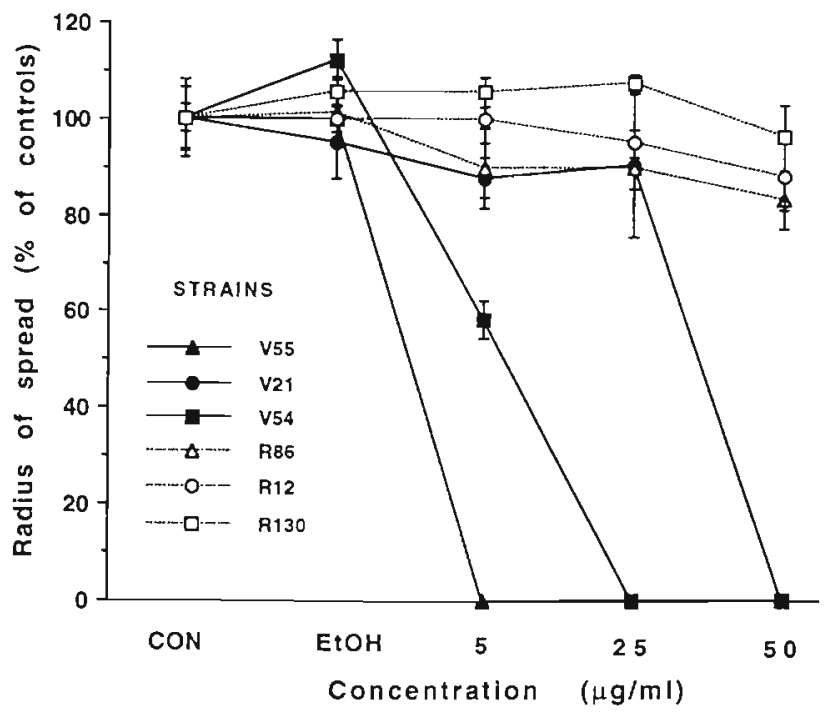

Fig. 7. Inhibition of swimming motility by furanone 2 for 3 bacterial isolates from Delisea pulchra (V55, V21, V54), and 3 from nearby submerged rocks (R86, R12, R130) tested on agar plates. Data are mean $\pm \mathrm{SE}$ for $\mathrm{N}=3$ plates for each strain at each concentration significantly more sensitive to furanones than isolates from rocks, as was observed in the more general screening (Fig. 3), although this could not be formally determined because strains from $D$. pulchra were grown on different media than those from rocks (see 'Materials and methods')

\section{DISCUSSION}

\section{Chemical mediation of marine eukaryote/bacterial interactions by secondary metabolites}

There is an extensive literature on the antibiotic effects of secondary metabolites or extracts from marine benthic invertebrates and algae against standard laboratory, or biomedically relevant, bacteria (e.g. Hornsey \& Hilde 1974, Al-Ogily \& Knight-Jones 1977, Reichelt \& Borowitzka 1984). However, there is very little

Table 6. Analysis of variance of growth, as measured by absorbance at $595 \mathrm{~nm}$ in liquid media, of 3 rock strains and 3 strains isolated from Delisea pulchra grown in the presence of furanones 1 to 4 at concentrations of $0,5,25$, and $50 \mu \mathrm{g} \mathrm{ml}^{-1}$. Analysis done after $10 \mathrm{~h}$ of growth. $\mathrm{N}=3$ cultures per combination of treatment

\begin{tabular}{|lrcc|}
\hline Factor & df & F-ratio & $\mathrm{p}$ \\
\hline Source/Media & 1 & 164.9 & $<0.0001$ \\
Strain (S/M) & 5 & 134.7 & $<0.0001$ \\
Furanone & 4 & 31.9 & $<0.0001$ \\
S/M $\times$ Strain & 4 & 11.6 & $<0.0001$ \\
Strain $\times$ Furan. & 20 & 20.9 & $<0.0001$ \\
Concentration & 4 & 29.5 & $<0.0001$ \\
Source $\times$ Conc. & 4 & 1.34 & 0.29 \\
Strain $\times$ Conc. & 20 & 42.7 & $<0.0001$ \\
Furan $\times$ Conc. & 16 & 16.8 & $<0.0001$ \\
Source $\times$ Furan. $\times$ Conc. & 16 & 8.4 & $<0.0001$ \\
Strain $\times$ Furan. $\times$ Conc. & 80 & 12.9 & $<0.0001$ \\
Error & 350 & & \\
\hline
\end{tabular}


known about how secondary metabolites mediate interactions between marine eukaryotes and their associated bacteria (see reviews by Davis \& Wright 1989. Hay 1996). In fact, to our knowledge, the research described here is the first time that characterised secondary metabolites from a marine eukaryote have been experimentally tested against bacteria associated with the eukaryote. Ecologically relevant evidence for the effects of secondary metabolites from marine bacteria against other marine organisms is also rare (e.g. Gil-Turnes et al. 1989). For the most part, evidence that secondary metabolites mediate interactions between marine eukaryotes and relevant bacteria is based on a small number of studies that (1) relate variation in eukaryotic secondary metabolites (usually measured within, rather than on the surface of, the host), or the activity of crude extracts, to bacterial abundance on host surfaces (Becerro et al. 1994. Wahl et al. 1994, Slattery 1995, Wahl 1995, this paper); (2) show that crude extracts from eukaryotes kill bacteria, or inhibit their growth or attachment (Becerro et al. 1994, Wahl et al. 1994, Slattery 1995, this paper); or (3) relate the settlement of invertebrate larvae to chemical cues produced by bacterial biofilms (Kirchman et al. 1982, Maki et al. 1988, Maki et al. 1990, Szewzyk et al. 1991, Holmström et al. 1992).

Both observational and experimental data indicate that furanones have strong inhibitory effects on bacteria from the alga or its habitat. Numbers of bacteria on Delisea pulchra were low, relative to those on other cooccurring algal species, and there was a strong inverse relationship between variation in bacterial numbers and furanone content (de Nys et al. 1996b, Dworjanyn et al. in press) along the alga. (While bacterial counts were done via scanning electron microscopy (SEM) after critical point drying, which can damage cell morphologies and thereby affect estimates of abundance of some cyanobacteria (Nagarkar \& Williams 1997) and diatoms, we saw little evidence of damaged morphologies of the bacteria counted here, which otherwise might have suggested artifacts in counting.] The relationship between bacterial numbers and furanones is correlative, but is not easily explained by potentially confounding factors such as the age of different parts of the alga, variation in local environmental conditions, or the growth pattern of the alga. The 3 other species of algae sampled in this study co-occur with $D$. pulchra, and thus variation in local conditions -- light, temperature, etc. - are unlikely to account for the observed differences in bacterial abundance. Moreover, like $D$. pulchra, both Sargassum vestitum and Laurencia rigida have apical growth, but numbers of bacteria on the latter 2 species do not decrease from the oldest (basal) to youngest (apical) tissue, as for D. pulchra. $S$. vestitum and $L$. rigida also produce secondary metabo- lites which inhibit fouling organisms in laboratory assays (Sieburth \& Conover 1965, Sieburth 1968, de Nys et al. 1996a), although it is unclear whether these metabolites are active in situ (Jennings \& Steinberg 1997, de Nys et al. 1998). The fourth species examined, Amphiroa sp, belongs to a group of algae (the Corallinaceae) which slough their epithallial layers (external cell layer; Johnson \& Mann 1986, Keats et al. 1997). Although epithallial sloughing has not been investigated specifically for Amphiroa sp, if present it should also substantially reduce fouling. However, numbers of bacteria on the surface of this alga were not significantly different from $L$. rigida or $S$. vestitum. Thus even in comparison with co-occurring algae that are thought to employ antifouling or antibacterial mechanisms, bacterial abundance on the surface of $D$. pulchraparticularly on apical portions - was low.

In laboratory assays, furanones or crude extract of Delisea pulchra inhibited a range of colonisation-relevant phenotypes, including swimming, attachment, growth, and swarming, of bacteria isolated from $D$. pulchra, Sargassum vestitum, or nearby rocks. Attachment of bacteria was also significantly inhibited in the field, as was also observed by Slattery et al. (1995) for extracts of Antarctic soft corals. Not all furanones were equally effective against all bacteria or phenotypes tested (see below), but the overall breadth and strength of inhibition observed in these assays suggests that these compounds are consistent inhibitors of bacterial colonisation in the field.

Importantly, bacteria in these assays were inhibited at ecologically realistic concentrations of furanones or crude extract. As Davis et al. (1989) and Hay (1996) point out, a crucial consideration in assessing the effects of eukaryote metabolites on bacterial fouling is the ability to measure concentrations of metabolites on or near the surface (rather than internally) of the producing organism, which is where epiphytic bacteria will contact the metabolites. We have measured concentrations of furanones on the surface of $D$. pulchra by dipping the plant in non-polar solvents which do not damage surface cells (de Nys et al. 1998, Dworjanyn et al. in press), similar to the technique used by Zobel \& Brown $(1988,1990)$ for terrestrial plants. Surface concentrations of individual furanones typically range between 10 and $250 \mathrm{ng} \mathrm{cm}^{-2}$ (depending on the furanone measured), occasionally exceed-

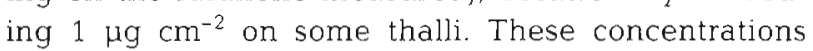
overlap the levels of metabolites or extract tested in the attachment assays. The concentrations used in agar plate assays for swimming, swarming or growth were volumetric $\left(\mu \mathrm{g} \mathrm{ml}^{-1}\right)$ and thus more difficult to relate to surface concentrations. However, if we assume that bacteria in assays on agar plates primarily contact metabolites in a slice consisting of the upper 
$100 \mu \mathrm{m}$ of the plate, then $10 \mu \mathrm{g} \mathrm{ml} \mathrm{m}^{-1}$ in the agar repre-

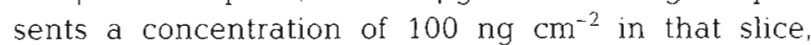
which is again well within the range of concentrations measured on the surface of the plant. Variation in concentration on the surface of different plants is also correlated with variation in whole plant concentrations (Dworjanyn et al. in press), indicating that previous measurements of variation in whole thallus chemistry are relevant to bacterial fouling of the alga, at least in a relative sense.

\section{Specificity of effects for furanones}

Perhaps the most notable aspect of our results was the complexity which characterised the inhibitory effects of furanones or crude extract on bacteria. These compounds were not in general simple inhibitors of growth, although for some strains and at some concentrations growth was strongly inhibited. However, by comparing the effects of furanones on growth to effects on other colonisation phenotypes, the gross effects of these compounds could be decoupled from their more specific effects (see Wahl et al. 1994 for a similar decoupling of growth and attachment). These more specific effects of furanones were strong but highly variable, differing among sources of bacteria (rocks vs Delisea pulchra, and for growth, Sargassum vestitum), among individual isolates from one source, among the 4 bacterial colonisation traits measured, and among the different furanones tested. This variation in the response of the bacteria was not consistent or predictable across phenotypes, or across sources of isolation. For example, attachment of rock strains was inhibited at much lower concentrations of crude extract than that of strains from $D$. pulchra, but growth of strains from $D$. pulchra was much more strongly affected than that of rock strains.

Because of the complexity of the bacterial attachment process, this characteristic by itself would potentially provide a wealth of possible targets for inhibition by furanones or other eukaryotic secondary metabolites (and possible counter adaptation by bacteria). Bacterial attachment is affected strongly by the physiological status of the cell (Fletcher 1996), the production of specific adhesins (Mittelman 1996), and the presence of specific receptor proteins on the surface of the cell (Doig et al. 1989) - all of which are thought to be under the control of specific genetic regulatory mechanisms. Indeed, several genes are thought to be specifically induced when the cell contacts a surface (Dalton et al. 1996). Potentially furanones may be acting on any of these bacterial characteristics, providing considerable scope for acting differentially against different bacteria. Attachment is also affected by physico- chemical characteristics of the surface, including its wettability or hydrophobicity (Dexter et al. 1975, Rosenberg et al. 1986), its net charge (Beveridge et al. 1997), the presence of conditioning films, and the presence of specific organic (e.g. Chet et al. 1975, Marshall 1996) or inorganic molecules (reviewed by Van Loosdrecht et al. 1989). However, we have found (Steinberg et al. 1998) that coating furanones or extract onto glass or plastic surfaces at the concentrations used in this study has relatively little effect on simple physicochemical properties of these surfaces (such as contact angles), suggesting that the compounds do not function simply by physically modifying surfaces (Steinberg et al. 1998).

As well as inhibiting attachment of bacteria, furanones also inhibited the bacterial surface spreading behaviour known as swarming (also see Givskov et al. 1996, Gram et al. 1996 for inhibition of swarming by furanones of non-marine bacteria). Such surface spreading behaviour may be very advantageous to surface associated bacteria (Allison \& Hughes 1991, Belas 1992), since it allows cells to rapidly colonise a surface (swarmer cells elongate, hyperflagellate and rapidly move over a surface; Belas 1992). Inhibition of this behaviour by host metabolites would thus keep a bacterial colony localised. Swarming is mostly known only for a number of common laboratory strains (Harshey 1994), and there is no indication of how widespread swarming is among bacteria from particular environments (information on swarming in marine bacteria is primarily restricted to studies of Vibrio parahaemolyticus, e.g. McCarter \& Silverman 1990, McCarter et al. 1992). However, approximately $25 \%$ of the 120 marine bacterial strains isolated from Delisea pulchra and rock surfaces in this study exhibited swarming, and many more may swarm under different nutrient and viscosity conditions that were not included in this study. Thus, swarming may be a widespread phenotype among marine surface associated bacteria, and play an important role in bacterial fouling in the aqueous environments.

Only 3 strains each from rock surfaces and Delisea pulchra were individually assayed for their reponse to furanones. This is a limited number of strains, although the results of these assays are consistent with the general screening of crude extract againts growth. Given this caveat, the differential effects of furanones on bacteria from different surfaces are intriguing, because the results are counterintuitive in a number of respects. Bacteria isolated from a host plant would be expected to perform better than non-host strains when exposed to an inhibitory component of that host, because of prior long-term exposure to those metabolites. However, while bacteria isolated from $D$. pulchra were more tolerant to furanones than those from rocks in the 
attachment assay, they were much less tolerant to the effects of furanones on growth. Moreover, growth of isolates from another alga-Sargassum vestitumwas more strongly inhibited by furanones than that of strains from rocks. Thus, furanones appear to differentially inhibit bacteria from host versus non-host surfaces, as well as bacteria from inanimate versus living surfaces. This differential inhibition of attachment and growth, as well as affecting overall bacterial abundance on the alga, should have strong effects on the species composition of bacteria on the alga's surface. For example, some individual bacterial strains may be inhibited from attaching to $D$. pulchra, or if they can attach, may subsequently be inhibited from growing (or spreading across the surface).

From the perspective of the bacteria, our results strongly suggest differential adaptation of bacteria to different host surfaces. Such adaptation may either be due to (1) bacteria that are specifically (constitutively) adapted to different host plants or surfaces, or (2) induction of particular genotypes within the same species of bacteria when they contact different surfaces (e.g. McCarter et al. 1992, Dalton et al. 1994). While these 2 possible alternatives cannot yet be completely distinguished, we note that the isolates used in the laboratory assays would have divided some tens to hundreds of times (i.e. generations) prior to their use in these assays, suggestive of a constitutive, rather than inducible, difference.

The prevalence of specific adaptations of marine bacteria to different living host surfaces is unknown, as is the extent to which different living hosts attract specialised assemblages of bacteria. Strains used in these assays were selected in part based on the distinctness of colony morphology relative to other strains, and may or may not be representative of other strains from these surfaces (although the effects of furanones on the 6 selected strains reflected their activity in the general screening for growth effects). Wahl (1995) found little evidence for specialisation of bacteria on different host ascidians in the Pacific and Bahamas. However, for some groups of eukaryotes, such as vertebrate parasites and insects on plants (Mitter \& Brooks 1983, Futuyma \& Moreno 1988, Thompson 1994), host specialisation to individual host species is common. Moreover, one of the major theories which explains host specialisation in terrestrial insects is specific adaptation to host plant chemistry which is distinct among different host species. This argument would seem applicable to chemically rich algae such as Delisea pulchra, and thus we might expect to find specialised species of bacteria on this host plant. Such specialisation would also be facilitated by the rapid potential for evolution by bacteria, relative to most eukaryotes.

\section{Specific interference by furanones with bacterial signalling systems?}

Increasingly, bacteria are seen as being capable of actively responding to the environment in a coordinated, 'multicellular' fashion, via the use of regulatory systems that are mediated by chemical signal/receptor systems (Kell et al. 1995). One such system, increasingly well studied, is the acylated homoserine lactone (AHL) regulatory system, the details of which are reviewed by Fuqua et al. (1996) and Swift et aI. (1996). This regulatory system uses AHLs as signal molecules to regulate a wide range of cell phenotypes which are important in the association of bacteria with higher organisms. These include swarming, exoenzyme production, antibiotic synthesis and swarming, as well as other phenotypes such as bioluminescence (Swift et al. 1994, Kell et al. 1995, Eberl et al. 1996b).

Furanones from Delisea pulchra show close structural similarity to AHL signal molecules (Givskov et al. 1996, Kjelleberg et al. 1997), and interfere specifically with a number of AHL regulated phenotypes in laboratory and marine bacteria without inhibiting growth. These phenotypes include swarming in Serratia liquefaciens, bioluminescence in Vibrio fischeri and V. harveyi, and a number of other presumed AHL phenotypes where the regulatory details are less well known (Givskov et al. 1996, Kjelleberg et al. 1997). Recent evidence from our group suggests that furanones inhibit these processes by binding to the $\mathrm{R}$ homologous receptor protein in the AHL regulatory loop, thereby preventing binding of AHLs at this site (M. Manefield unpubl.).

Thus one possible explanation for the effects of furanones as specific inhibitors of particular phenotypes against the bacteria tested here is that they interfere with AHL (or analogous) regulatory systems in marine bacteria which regulate these phenotypes. Although the presence of AHL systems has not yet been demonstrated in these bacteria, this result is consistent with several observations. First, the compounds interfere with specific phenotypes at non-growth-inhibitory concentrations. One of these traits-swarming - is a known AHL phenotype in other bacteria (Eberl et al. $1996 a, b)$. Second, different furanones have different effects, as would be expected if analogous AHL systems in different bacteria are regulated by slightly different signals (AHLs) or receptors, as is the case for many characterised AHL systems (Swift et al. 1996). Moreover, because AHL regulatory systems govern a wide range of phenotypes in bacteria, interference with such systems would provide an explanation as to how furanones could inhibit a broad array of bacterial phenotypes while having no overall effect on growth or survival. 
Since many bacterial phenotypes are under the control of specific regulatory systems mediated by chemical signals, there is considerable scope for interference by host secondary metabolites. Manipulation of such regulatory systems may have no effect on growth, while strongly influencing bacterial fouling capabilities. We have shown that the effects of furanones on bacterial colonisation phenotypes are due to interference with specific cell processes rather than to toxicity or general surface modification. Interference with AHL autoinduction provides one potential mechanistic explanation for these effects.

Acknowledgements. This research was supported by Australian Research Council Large Grants to P.D.S. and S.K., an ARC Postdoctoral Fellowship to R. de N., the Danish Technical research Council, the Danish Centre for Microbial Ecology, Lovens Kemiske A/S, and the Carlsberg Foundation.

\section{LITERATURE CITED}

Al-Ogily SM, Knight-Jones EW (1977) Anti-fouling role of antibiotics produced by marine algae and bryozoans. Nature 265:728-729

Allison C. Hughes C (1991) Bacterial swarming: an example of prokaryotic differentiation and multicellular behaviour. Sci Prog Edinburgh 75:403-422

Becerro MA, Lopez NI, Turon X, Uriz MJ (1994) Antimicrobial activity and surface bacterial film in marine sponges. J Exp Mar Biol Ecol 179:195-205

Belas R (1992) The swarming phenomenon of Proteus mirabilis. ASM News 58:15-22

Beveridge TJ, Makin SA, Kadurugamuwa JL, Li Z (1997) Interactions between biofilms and the environment. FEMS Microbiol Rev 20:291-303

Chet I, Asketh P. Mitchell R (1975) Repulsion of bacteria from marine surfaces. Appl Microbiol 30:1043-1045

Dalton H, Goodman AE, Marshall KC (1996) Diversity in surface colonisation behaviour in marina bacteria. J Ind Microbiol 17:228-234

Dalton HM, Poulsen LK, Halasz P, Angles ML, Goodman AE, Marshall KC (1994) Substratum-induced morphological changes in a marine bacterium and their relevance to biofilm structure. J Bacteriol 176:6900-6906

Davis AR, Targett NM, McConnell OJ, Young CM (1989) Epibiosis of marine algae and benthic invertebrates: natural products chemistry and other mechanisms inhibiting settlement and overgrowth. Bioorg Mar Chem 3:86-114

Davis AR, Wright AE (1989) Interspecific differences in fouling of two congeneric ascidians (Eudistoma olivaceum and E. capsulatum): is surface acidity an effective defence? Mar Biol 102:491-497

Day RW, Quinn GP (1989) Comparisons of treatments after an analysis of variance in ecology. Ecol Monogr 56:345-363

de Nys R, Dworjanyn SA, Steinberg PD (1998) A new method for determining surface concentrations of marine natural products on seaweeds. Mar Ecol Prog Ser 162:79-87

de Nys R, Leya T, Maximilien R, Afsar A, Nair PSR, Steinberg PD (1996a) The need for standardised broad scale bioassay testing: a case study using the red alga Laurencia rigida. Biofouling $10(1-3): 213-224$

de Nys R, Steinberg PD, Rogers CN, Charlton TS, Duncan MW (1996b) Quantitative variation of secondary metabo- lites in the sea hare Aplysia parvula and its host plant, Delisea pulchra. Mar Ecol Prog Ser 130:135-146

de Nys R, Steinberg PD, Willemsen P, Dworjanyn SA, Gabelish CL, King RJ (1995) Broad spectrum effects of secondary metabolites from the red alga Delisea pulchra in antifouling assays. Biofouling 8:259-271

de Nys R, Wright AD, Konig GM, Sticher O (1993) New halogenated furanones from the marine alga Delisea pulchra (cf. fimbriata). Tetrahedron 49:11213-11220

Dexter SC, Sullivan JDJ, Williams J, Watson SW (1975) Influence of substrate wettability on the attachment of marine bacteria to various surfaces. Appl Microbiol 30:298-308

Doig P, Tapping R, Mankinen-Irvin P, Irvin RT (1989) Effect of microcolony formation on the adherence of Pseudomonas aeruginosa to human buccal epithelial cells. Microbial Ecol Health Dis 2:203-209

Dworjanyn S, de Nys R, Steinberg PD (in press) Localisation and surface chemistry of secondary metabolites in the red alga Delisea pulchra. Mar Biol

Eberl L, Christiansen G, Molin S, Givskov M (1996a) Differentiation of Serratia liquefaciens into swarm cells is controlled by the expression of the flhD master operon. $J$ Bacteriol 178:554-559

Eberl L, Winson MK, Sternberg C, Stewart GSAB, Christiansen G, Chhabra SR, Bycroft B, Williams P, Molin S, Givskov $M$ (1996b) Involvement of $N$-acyl-L-homoserine lactone autoinducers in controlling the multicellular behaviour of Serratia liquefaciens. Mol Microbiol 20 : $127-136$

Fenical W (1993) Chemical studies of marine bacteria: developing a new resource. Chem Rev 93:1673-1683

Fletcher M (1996) Bacterial attachment in aquatic environments: a diversity of surfaces and adhesion strategies. In: Fletcher M (ed) Bacterial adhesion: molecular and ecological diversity. John Wiley \& Sons, New York, p 1-24

Fuqua C, Winans SC, Greenberg EP (1996) Census and consensus in bacterial ecosystems: the LuxR-LuxI family of quorum-sensing transcriptional regulators. Annu Rev Microbiol 50:727-751

Futuyma DJ, Moreno G (1988) The evolution of ecological specialisation. Annu Rev Ecol Syst 19:207-233

Gil-Turnes MS, Hay ME, Fenical W (1989) Symbiotic marine bacteria defend crustacean embryos from a pathogenic fungus. Science 240:116-118

Givskov M, de Nys R, Manefield M, Gram L, Maximilien R, Eberl L, Molin S, Steinberg PD, Kjelleberg S (1996) Eukariotic interference with homoserine lactone-mediated prokariotic signalling. J Bacteriol 178:6618-6622

Gram L, de Nys R, Maximilien R, Givskov M, Steinberg PD, Kjelleberg $S$ (1996) Inhibitory effects of secondary metabolites from the red alga Delisea pulchra on swarming motility of Proteus mirabilis. Appl Environ Microbiol 62:4284-4287

Harshey RM (1994) Bees aren't the only ones: swarming in Gram-negative bacteria. Mol Microbiol 13:389-394

Hay ME (1996) Marine chemical ecology: what's known and what's next? J Exp Mar Biol Ecol 200:103-134

Holmström C, Rittschof D, Kjelleberg S (1992) Inhibition of settlement by larvae of Balanus amphitrite and Ciona intestinalis by a surface-colonising marine bacterium. Appl Environ Microbiol 58:2111-2115

Hornsey IS, Hilde D (1974) The production of antimicrobial compounds by British marine algae. I. Antibiotic producing algae. Br Phycol J 9:353-361

Jennings JG, Steinberg PD (1997) Phlorotannins vs. other factors affecting epiphyte abundance on the kelp Ecklonia radiata. Oecologia 109:461-473 
Jenson PJ, Fenical W (1994) Strategies tor the discovery of secondary metabolites from marine bactena: ecological perspectives. Annu Rev Microbiol 48:559-584

Johnson CR, Mann KH (1986) The crustose coralline alga, Phymatolithon Foslie, inhibits the overgrowth of seaweeds without relying on herbivores. J Exp Mar Biol Ecol 96: $127-146$

Kazlauskas R, Murphy PT, Quinn RJ, Wells RJ (1977) A new class of halogenated lactones from the red alga Delisea fimbriata (Bonnemaisoniaceae). Tetrahedron Lett 1:37-40

Keats DW, Knight MA, Pueschel CM (1997) Antifouling effects of epithallial shedding in three crustose coralline algae (Rhodophyta, Corallinales) on a coral reef. J Exp Mar Biol Ecol 213:281-293

Kell DB, Kaprelyants AS, Grafen A (1995) Pheromones, social behaviour and the functions of secondary metabolism in bacteria. Trends Ecol Evol 10:126-129

Kirchman D, Graham S, Reish D, Mitchell R (1982) Bacteria induce settlement and metamorphosis of Janua (dexiospira) Brasiliensis grube (polychaete: Spirorbidae). J Exp Mar Biol Ecol 56:153-163

Kjelleberg S, Steinberg P, Givskov M, Gram L, Manefield M, de Nys R (1997) Do marine natural products interfere with prokaryotic AHL regulatory systems? Aquat Microb Ecol 13:85-93

Kushmaro YL, Fine M, Rosenberg E (1996) Bacterial infection and coral bleaching. Nature 380:396

Littler MM, Littler DS (1995) Impact of CLOD pathogen on Pacific coral reefs. Science 267:1356-1360

Maki JS, Rittschof D, Costlow JD, Mitchell R (1988) Inhibition of attachment of larval barnacles, Balanus amphitrite, by bacterial surface films. Mar Biol 97:199-206

Maki JS, Rittschof D, Samuelsson MO, Szewzyk U, Yule AB, Kjelleberg S, Costlow JD, Mitchell R (1990) Effect of marine bacteria and their exopolymers on the attachment of barnacle cypris larvae. Bull Mar Sci 46:499-511

Marden P, Tunlid A, Malmcrona-Friberg K, Odham G, Kjelleberg $S$ (1985) Physiological and morphological changes during short term starvation of marine bacterial isolates. Arch Microbiol 142:326-332

Marshall KC (1996) Adhesion as a strategy for access to nutrients. In: Fletcher $M$ (ed) Bacterial adhesion: molecular and ecological diversity. John Wiley \& Sons, New York, p 56-88

McCarter LL, Showalter RE, Silverman MR (1992) Genetic analysis of surface sensing in Vibrio parahaemolyticus. Biofouling 5:163-175

McCarter LL, Silverman MR (1990) Surface-induced swarner cell differentiation of Vibrio parahaemolyticus. Mol Microbiol 4:1057-1062

Mittelman MW (1996) Adhesion to biomaterials. In: Fletcher $M$ (ed) Bacterial adhesion: molecular and ecological diversity. John Wiley \& Sons, New York, p 89-128

Mitter C, Brooks DR (1983) Phylogenetic aspects of coevolution. In: Futuyma DJ, Slatkin M (eds) Coevolution. Sinauer Associates Inc, Sunderland, MA, p 65-98

Nagarkar S, Williams GA (1997) Comparative techniques to quantify cyanobacteria dominated epilithic biofilms on tropical rocky shores. Mar Ecol Prog Ser 154:281-291

Reichelt JL, Borowitzka MA (1984) AntimicrobiaI activity from marine algae: results of a large-scale screening pro-

Editorial responsibillty: John Dolan,

Villefranche-sur-Mer, France gramme. Hydrobiologia 116/117:158-168

Rosenberg M, Kjelleberg S (1986) Hydrophobic interactions: role in bacterial adhesion. In: Marshall KC (ed) Advances in microbial ecology, 9. Plenum Press, London, p 353-393

Sieburth J, Conover JT (1965) Sargassurn tannin, an antibiotic which retards fouling. Nature 208:52-53

Sieburth JM (1968) The influence of algal antibiosis on the ecology of marine microorganisms. In: Droop MR, Wood EJF (eds) Advances in microbiology of the sea. Academic Press, New York, p 63-94

Sieburth JM (1979) Sea microbes. Oxford University Press, New York

Slattery M, MCClintock JB, Heine JN (1995) Chemical defences in Antarctic soft corals; evidence for antifouling compounds. J Exp Mar Biol Ecol 190:61-77

Sokal RR, Rohlf FJ (1995) Biometry, 3rd edn. WH Freeman, San Francisco

Steinberg PD, de Nys R, Kjelleberg S (1998) Chemical inhibition of epibiota by Australian seaweeds. Biofouling 12 : $227-244$

Swift S, Bainton NJ, Winson MK (1994) Gram-negative bacterial communication by $N$-acyl homoserine lactones: a universal language? Trends Microbiol 2:193-198

Swift S, Throup JP, Williams P, Salmond GPC, Stewart GSAB (1996) Quorum sensing: a population-density component in the determination of bacterial phenotype. TIBS 21 : $214-219$

Szewzyk $U_{1}$ Holmström $C$, Wrangstadh $M$, Sarnuelsson $M O$, Maki JS, Kjelleberg S (1991) Relevance of the exopolysaccharide of marine Pseudomonas sp. Strain S9 for the attachment of Ciona intestinalis larvae. Mar Ecol Prog Ser 75:259-265

Thompson JN (1994) The coevolutionary process. Univ Chicago Press, Chicago

Todd JS, Zimmerman RC, Crews P, Randall SA (1993) The antifouling activity of natural and synthetic phenolic acid sulfate esters. Phytochem 34:401-404

Underwood AJ (1981) Techniques of analysis of variance in experimental marine biology and ecology. Oceanogr Mar Biol Annu Rev 19:513-605

Unson MD, Holland ND, Faulkner DJ (1994) A brominated secondary metabolite synthesised by the cyanobacterial symbiont of a marine sponge and accumulation of the crystalline metabolite in the sponge tissue. Mar Biol 119:1-11

Van Loosdrecht MCM, Lyklema J, Norde W, Zehnder AJB (1989) Bacterial adhesion: a physicochemical approach. Microb Ecol 17:1-15

Wahl M (1995) Bacterial epibiosis on Bahamian and Pacific ascidians. J Exp Mar Biol Ecol 191:239-255

Wahl M (1996) Fouled snails in flow: potential of epibionts on Littorina littorea to increase drag and reduce snail growth rates. Mar Ecol Prog Ser 138:157-168

Wahl M, Jensen PR, Fenical W (1994) Chemical control of bacterial epibiosis on ascidians. Mar Ecol Prog Ser 110: $45-57$

Zobel AB, Brown SA (1988) Determination of furanocumarins on the leaf surface of Ruta graveolens with an improved extraction technique. J Nat Prod 51:941-946

Zobel AB, Brown SA (1990) Dermatitis-inducing furanocumarins on the leaf surfaces of eight species of rutaceous and umbelliferous plants. J Chem Ecol 16:693-700

Submitted: January 15, 1988; Accepted: April 2, 1998

Proofs received from author(s): August 3, 1998 